\title{
Germany gets warning on access to sequence data
}

[MUNICH] Germany's efforts to improve its standing in the international genetics community are threatened by a controversy about rules giving German industry three months' privileged access to the results of research funded by the government through its human genome research programme.

The research programme was launched by the research ministry in 1995 . It has recently been agreed that all researchers receiving support through the programme will in future have to make their data available to a new German industrial funding association, Verein zur Förderung der Humangenomforschung.

The idea is to give German drug companies involved in the association three months' privileged access to the data. But the proposed rule has led to a threat from the directors of several large genome sequencing centres in the United States, the United Kingdom and France that they will block access to their sequence data for German scientists and industry.

In response to the threat, the research ministry says it will suspend the agreement with the association until the issue is resolved. A meeting will be held in Bonn at the end of the month with representatives of the association and the international academic community to try to resolve the conflict. Until then, German researchers will remain free to publish and distribute their data as they wish. But they have been forbidden to disclose details of the conflict.

The association was set up by German industry in response to criticism that industry had declined to contribute to the human genome programme, which was intended to be financed equally by the government and industry to a total of DM400 million (US\$232 million) over four years (see Nature 378,6 ; 1995).

In contrast, several companies have forged bilateral links with genomics companies in the United States. Hoechst last month formed a US\$85-million joint venture with Ariad Pharmaceuticals in Cambridge, Massachusetts, to develop small molecules to regulate gene function in target diseases.

The new association includes the drug companies Asta Medica, Bayer, BASF, Boehringer Ingelheim, Boehringer Mannheim, Hoechst, Merck and Schering. Each is understood to have agreed to contribute DM150,000 a year.

The money will be used primarily to support a Patent and Licensing Agency. This will have three months to review findings resulting from ministry-funded research and, where considered appropriate, to file patents on behalf of researchers. The agency will pay the filing costs, and any member of the association can then bid for the patent rights.

But the plan drew an angry response from the scientific community when it was unveiled by Ursula Hurtenbach, who organizes the human genome research programme for the research ministry, at an international strategy meeting on human genome sequencing in Bermuda in February.

At the first such meeting, held in Bermuda in 1996, most of the publicly funded human genome centres represented agreed to the principle that all genetic information should be made freely available to scientists and industry (see Nature 371, 365 \& 551; 1994).

Participants at both meetings included John Sulston, director of the UK Sanger Centre, Jean Weissenbach from Généthon in Paris, Michael Morgan of the Wellcome Trust in London, and Francis Collins, director of the National Center for Human Genome Research at the National Institutes of Health in Bethesda, Maryland.

They told Germany at this year's meeting that its research institutes would be excluded from the previous consensus agreement if plans for the new association were not changed. All four participants have been invited to take part in the Bonn negotiations, which will be chaired by Josef Straus, director of the Max Planck Insitute for Foreign and International Patent Copyright and Competition Law in Munich.

Many German scientists are worried at the prospects of being excluded from the agree-

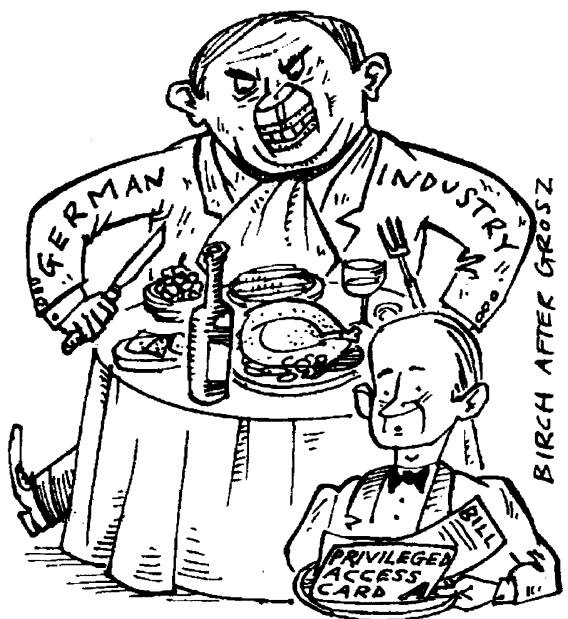

ment. "If the research ministry and the association continue to insist on privileged access, scientists and industrial participants are likely to lose access to 90 per cent of the genomic sequence information generated by international centres", says André Rosenthal, head of the department of genome analysis at the Institute for Molecular Biotechnology in Jena. Rosenthal expects to receive a grant from the ministry of around DM20 million for a threeyear project to sequence 40 megabases on human chromosomes 21 and $\mathrm{X}$.

But German companies are maintaining their hard-line stance. "We will never support research whose findings are distributed indiscriminately," says Rolf Krebs, a member of Boehringer Ingelheim's executive board.

The companies also argue that the US patent system gives a considerable competitive edge to US industry because it allows a 'grace period' under which patents can be applied for up to one year after the publication of research results. To compete effectively, the companies argue, European industry needs privileged access to the results of European research.

Robert Unterhuber

\section{Rüttgers and Chirac seek cloning ban}

[PARIS] Germany's research minister, Jürgen Rüttgers, last week backed a call by the French president, Jacques Chirac, for a worldwide ban on human cloning. Chirac, who made the statement on the same day he received a commissioned report on the subject from the French national bioethics committee, declared his "vehement, categoric and definitive ethical condemnation of all reproductive cloning of human beings".

Rüttgers also presented a statement from seven leading German scientific experts on the biological, ethical and legal aspects of cloning. He said he agreed with their conclusion that the cloning of humans is ethically unjustifiable, and called for the rapid introduction of an international ban. In Germany, human cloning has been illegal since 1990, the maximum punishment being five years in prison. France's 1994 bioethics laws also ban human cloning.

"Cloned humans in any part of the world would mean an attack on the dignity and integrity of every single man on Earth", said Rüttgers, adding that the
Council of Europe's convention on bioethics should be modified to ban cloning explicitly. Chirac said he would raise the issue at the next summit of the G7 countries in June. He suggested that the International Bioethics Committee of the United Nations Educational, Scientific and Cultural Organization, which is chaired by Noëlle Lenoir of France's constitutional council, was the "natural forum" for introducing an international ban.

Declan Butler \& Quirin Schiermeler 